\title{
Kosmiczna odyseja morska
}

\author{
Emilia Kiełtyka \\ Uniwersytet Gdański \\ Wydział Oceanografii i Geografii, Instytut Oceanografii \\ E-mail: kiel-emi@wp.pl \\ tutor: dr hab. Anita Lewandowska, prof. UG \\ Uniwersytet Gdański \\ Wydział Oceanografii i Geografii, Instytut Oceanografii, Zakład Chemii Morza i Ochrony Środowiska Morskiego
}

Stowa kluczowe: kosmos, ocean, głębiny, wszechświat, dusza, woda

\section{Woda to żywioł. Woda to życie}

Woda to środowisko życia. Jest składową ciała człowieka, ale także symbolem chaosu, odrodzenia i zmiany. Woda to początek, materia pierwotna, można powiedzieć, że to „Matka Życia na Ziemi”. Jednak jeszcze 4,6 mld lat temu na powierzchni naszej planety nie było tej cudownej substancji. Nie było wody, nie było powietrza, nie było także życia. Pierwotna, gorąca atmosfera nie zawierała tlenu, tworzyły ją głównie wodór i hel, pozostałości po Wielkim Wybuchu [1]. Znaczny spadek temperatury w atmosferze doprowadził do skroplenia pary wodnej, a na Ziemię spadły pierwsze opady deszczu. Powstały rzeki, jeziora, morza i oceany. Wody pokryły powierzchnię naszej planety i wówczas, w procesie łączenia się związków chemicznych powstał tlen. Była już woda, było powietrze, zaczęło pojawiać się życie [2].

Świat został tak skonstruowany, że wszystko wzajemnie się w nim przenika.
Woda pokrywa Ziemię. Ziemię otacza powietrze atmosferyczne. Człowiek składa się aż w $60 \%$ z wody, a każda żywa istota na naszym globie potrzebuje jej do życia i prawidłowego funkcjonowania. Oddychamy powietrzem, które nas otacza. Atmosfera chroni życie na Ziemi dzięki pochłanianiu promieniowania słonecznego o szkodliwych dla niego właściwościach. Niewidoczna dla ludzkiego oka para wodna unosi się w niebiosa, aby tam zamienić się w chmurę lub mgłę [3]. W świecie wszystko jest spójne. Natura jest kwintesencją doskonałości.

Zdaniem wielu naukowców zjawiska występujące w głębinach mają wiele wspólnego z tym, co dzieje się w kosmosie. Cząsteczki wody zachowują się tak samo, jak fotony wpadające do czarnych dziur. Profesor fizyki teoretycznej cząstek elementarnych i kosmologii w Instytucie Nielsa Bohra Troels Harmark powiedział, że "woda $\left(\mathrm{H}_{2} \mathrm{O}\right)$ składa się z mikroskopijnych molekuł, a te z kolei z podstawowych atomów i cząstek". Jednak badając wodę, możemy zaobserwować jedynie jej cechy makroskopowe, takie jak temperatura czy ciśnienie. Obecnie dość dobrze udało się także rozpoznać niektóre cechy makroskopowe czarnych dziur (np. masę 
i temperaturę). Nic nie wiadomo natomiast na temat mikroskopowych bloków budulcowych, z jakich się one składają" [4]. Czy zatem życie oceaniczne może być przyrównane do życia w kosmosie? Skoro Kosmos i Głębia są w dalszym ciągu nieodkrytym bezmiarem, może prawda leży pośrodku? Może, aby dostrzec głębię, warto popatrzeć w górę?

\section{Woda jest żywiołem-żywioł stanowi odnowienie}

Woda jest żywiołem. Z drugiej strony warunkuje istnienie życia na naszym globie, gdyż zajmuje aż 2/3 jego powierzchni. Znajduje się w otaczającej nas atmosferze oraz w lodzie pokrywającym skorupę Ziemską. Nie zapominajmy jednak, że woda posiada również swoją sferę sacrum. Przez swoje życiodajne właściwości uznawana jest za fundament wszelkiego istnienia. Zawsze też pełniła znaczącą rolę w mitach i wierzeniach. Uważano, że z wód chaosu powstaje życie. Tak opisywały to zarówno Wedy, święte księgi Hinduizmu, jak i mity greckie, w których Oceanos utożsamiany był z morzem [5]. Nawet dzisiaj wierzymy, że duchowe oczyszczenie dokonuje się poprzez chrześcijański chrzest, islamską rytualną ablucję czy zanurzenie w świętej indyjskiej rzece Ganges. Właściwie nie ma też kontynentu, na którym nie słyszano o wielkim potopie zesłanym przez Boga. Ten biblijny miał na celu zakończenie pewnej epoki. Życiodajna woda miała odnowić świat, położyć kres istnieniu wszystkich ludzi, którzy sprowadzili na Ziemię zło i odwrócili się od Boga ( $\mathrm{Rdz} 6$ ). W ten sposób każda historia zatacza swoje koło. Po każdej burzy nastaje cisza. Ocean znów staje się spokojny. Następuje odrodzenie. Można powiedzieć, że w ten sposób przenikają się zachwyt i groza. Ten dualizm jest tak bardzo charakterystyczny dla naszego świata. Zło i dobro zawsze w którymś momencie się spotykają. A to spotkanie jest nierozerwalnie związane z duszą ludzką. Tą tak bardzo nierozpoznaną, niezbadaną i niemożliwą do ogarnięcia sferą człowieka. Wszyscy jednak chcemy wierzyć, że nasze życie charakteryzuje jakaś głębia. Historie ludzkie pokazują, że najczęściej dochodzimy do niej przez całe nasze życie. Czy jednak istnieje paralela między głębią oceaniczną, a tą ludzką? Czy ujrzenie swojej prawdziwej głębi dokonuje się w momencie, kiedy dajemy się ponieść w nieznane wierząc, że i tak dotrzemy do celu.

Nawet w najgłębszej ciemności odnajdzie się światło

Z greckiego ábyssos to bezdenna otchłań, bezkres głębi [6]. Można ją postrzegać na różne sposoby. Może to być ogromna odległość od powierzchni oceanu do jego dna, jak również przestrzeń czy wielkość kontekstów, w których możemy rozumieć różnego rodzaju znaczenia kultury.

Morskie głębiny są nadal najmniej rozpoznanymi rejonami na naszej planecie. Warunki tam panujące są niezwykle wymagające dla istot żywych. Przykładowo ciśnienie jest aż 1000 razy wyższe niż na powierzchni, co sprawia, że organizmy żyjące przy powierzchni nie byłyby w stanie tam egzystować. Nie wytrzymałyby ciśnienia, które jest większego niż 300 atmosfer [7]. Z kolei temperatura wody spada wraz z głębokością. W górnych warstwach wynosi ona w skali globu średnio $17,4^{\circ} \mathrm{C}$, na $1500-$ $4000 \mathrm{~m}$ już tylko $3-4^{\circ} \mathrm{C}$, a głębiej nawet mniej [8]. Brak światła słonecznego sprawia, że panują tam całkowite ciemności. Najgłębszymi rejonami oceanów są rowy oceaniczne. Na Ziemi jest około 50 głównych rowów oceanicznych, które w sumie pokrywają około 0,5\% powierzchni oceanu. Sięgają one głębiej niż 6000 metrów pod poziomem morza. Najgłębszym rowem jest Rów Mariański, który mierzy ponad 10000 metrów. 


\section{Tutoring Gedanensis}

Te tajemnicze obniżenia oceaniczne to kopalnie niezbadanych organizmów, zasobów mineralnych oraz surowców. Co ciekawe, w każdym z rowów życie ewoluowało niezależnie, dlatego miejsca te stanowią prawdziwą zagadkę pod względem biologicznej różnorodności.

Jak widać nawet $w$ tak trudnych warunkach, choć z pozoru wydaje się to niemożliwe, kwitnie życie. Organizmy, które zamieszkują głębiny wykształciły szczególne cechy, które pozwalają im w nich egzystować. Najwięcej jest tu ryb, meduz, mięczaków i skorupiaków, ponieważ zwierzętom tym łatwiej było dostosować się do panujących tam warunków. Ciemność wypełniająca otchłań sprawiła, że wiele gatunków zatraciło narządy wzorku, bądź też wykształciło niezmiernie duże, teleskopowe oczy. Na ryc. 1. została zaprezentowana ryba z rodziny $\mathrm{Me}^{-}$ lanocetidae, która posiada na czubku swojej głowy antenę-wabik zakończoną świecącym wyrostkiem. Pozwala jej to zwabić ofiary i przyciągnąć partnerów nawet w całkowitych ciemnościach.

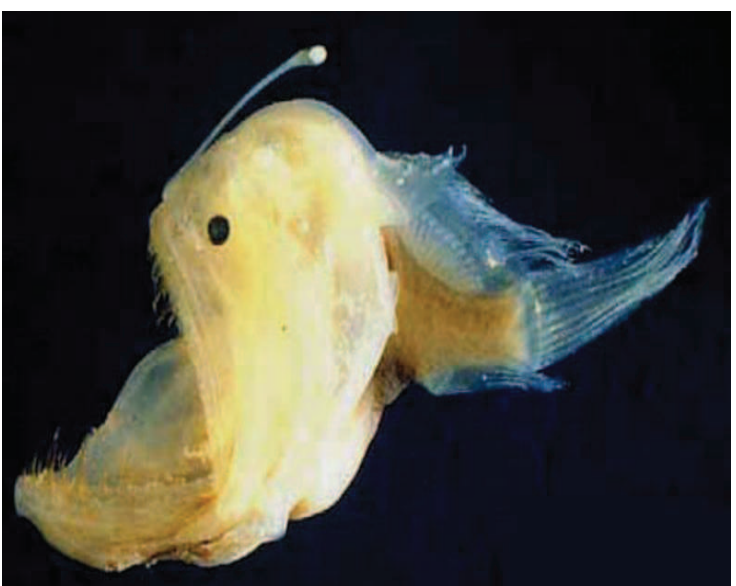

Ryc. 1. Ryba z rodziny Malanocetidae [9]

Ryba na statywie (Ryc. 2) jest praktycznie ślepa, dlatego wykształciła długie i kościste płetwy, które pomagają jej zdobyć pożywienie. Płetwy te działają niczym czułki i pozwalają rybie wyczuć zbliżającą się ofiarę.

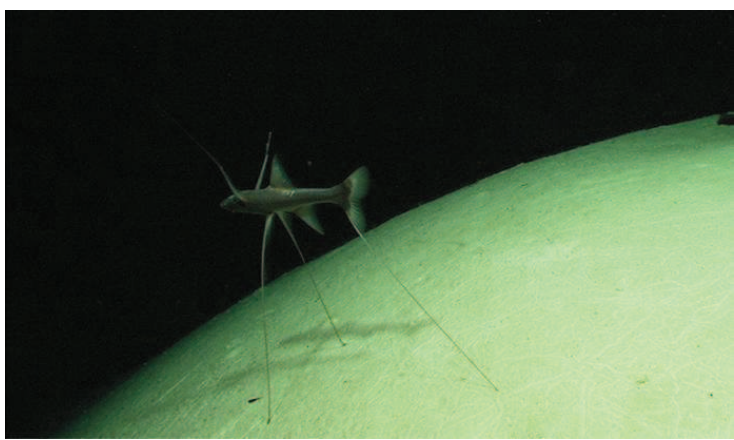

Ryc. 2.Ryba na statywie Bathypterois grallator [10]

Najczęściej występującym w tej strefie mięczakiem jest wampirzyca piekielna (Ryc. 3). Zwierzę to posiada duże, okrągłe narządy świetlne na końcu każdej płetwy, płaszczu, lejku i głowie. Za ich pomocą wytwarza luminescencyjne świecące cząsteczki. Świecą również jej końcówki ramion i podstawy płetw.

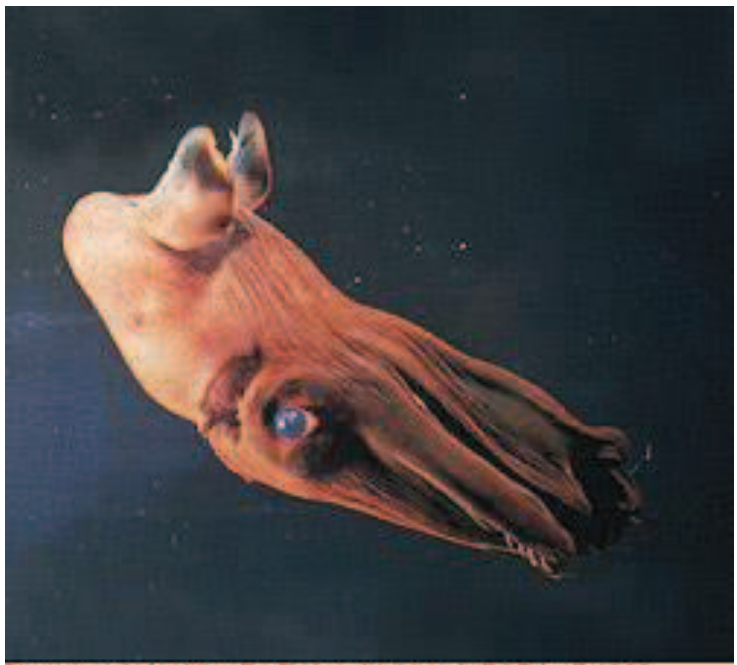

Photograph by Kim R. Reisenbichler, MBARI. (9)1996

Ryc. 3. Wampirzyca piekielna Vampyroteuthis infernalis [11]

Życie w tak ekstremalnych warunkach znacząco utrudnia znalezienie partnera oraz wydawanie potomstwa. Dlatego ośmiornice Dumbo (Ryc. 4) wykształciły umiejętność rozmnażania za każdym razem, kiedy znajdą partnera. Po kopulacji z samcem, samice potrafią przechowywać nasienie 
do czasu, aż warunki środowiskowe będą odpowiednie do wydania potomstwa.

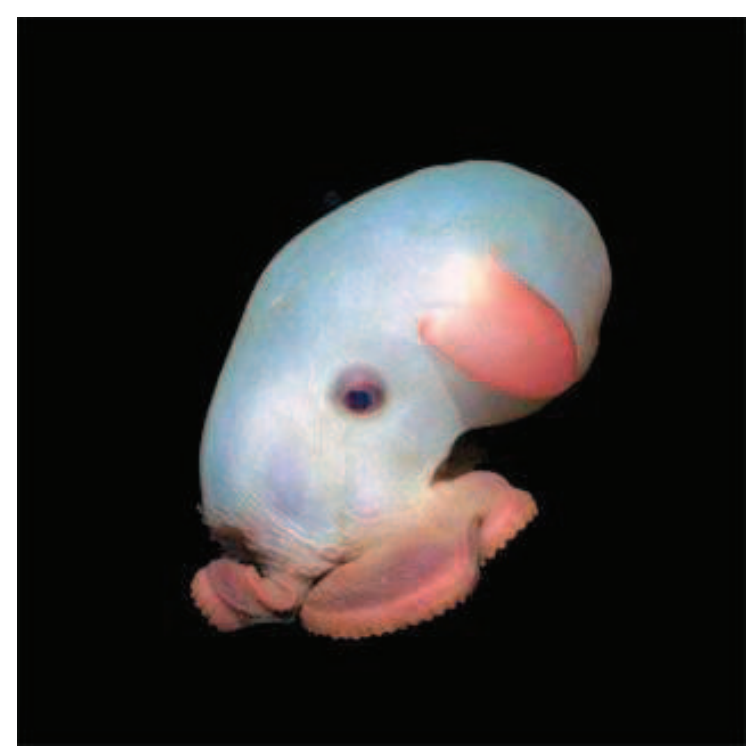

Ryc. 4. Ośmiornica z rodziny Grimpoteuthis [12]

Czyż stworzenia głębinowe nie są prawdziwymi indywiduami morskiego świata? Na przykładzie głębin oceanicznych i żyjących tam organizmów można stwierdzić, że wola przetrwania jest tam wielka, a "życie” musi się tam charakteryzować wielką siłą. Siłą, która poradzi sobie nawet w najtrudniejszych warunkach. Nawet w najgłębszej ciemności odnajdzie światło. Czy tak samo jest z naszą duszą? To, że droga do wnętrza człowieka, do poznania jego duszy jest trudna, jest faktem. Jednak chyba tylko tam można odnaleźć to, co najbardziej istotne. Należy tylko otworzyć szeroko oczy, wziąć głęboki wdech i popłynąć na te nieznane wody.

\section{Podsumowanie}

Prowadzenie badań w głębinach morskich, a zwłaszcza rowach oceanicznych, wydaje się trudniejsze od zdobycia Mount Everest. Warunki tam panujące znacznie utrudniają uzyskanie informacji, które poszerzyłyby wiedzę na temat tego niezwykle intrygującego środowiska. Jednak postęp techniki i możliwości ludzi ciągle się zwiększają. Ostatnie doniesienia na ten temat są bardzo obiecujące także dla eksploracji oceanów. Naukowcy NASA prze-testowali nowego robota [13], którego skonstruowano w oparciu o obserwację stworzeń zamieszkujących głębiny. Konstruktorzy zainspirowali się naturą i stworzyli miękką, automatyczną maszynę, która swoją budową przypomina płaszczkę. Z łatwością włącza się ona w rytm środowiska oraz nie płoszy i nie krzywdzi w żaden sposób podwodnych mieszkańców. Być może wynalazek ten pozwoli ludziom lepiej poznać tajemnice oceanicznych głębin i zrozumieć, jak ewoluowało życie w oceanie oraz jak przystosowywało się ono do zachodzących na naszym globie zmian.

Jest jednak jeszcze inny ważny aspekt badania oceanów i ich głębin. Tkwi w nas, ludziach, niezwykła chęć poznania nieznanego. $Z$ tego samego powodu, co dno oceanu, staramy się zrozumieć swoją duszę. Szukamy odpowiedzi na ważne pytania, czasami bez szansy powodzenia. Identycznie jak organizmy bytujące $\mathrm{w}$ niesprzyjających im głębinach, pragniemy żyć. Nawet wtedy, kiedy wydaje się to trudne, a wręcz niemożliwe. Płyniemy przez życie jak przez ocean, niezależnie od tego, czy mamy światło, czy otacza nas mrok. Staramy się zrozumieć siebie i otaczający nas wszechświat. Być może to, co jest dla nas najważniejsze, wcale nie jest tak odległe i takie trudne do osiągnięcia. Może ostatecznie wypłynie gdzieś z naszego wnętrza? Z naszych najgłębszych otchłani. Być może warto przyjrzeć się głębi siebie? Bo nie tylko głębiny oceanów są ważne dla przyszłości naszego świata. 


\section{Źródła internetowe:}

[1] https://pl.wikipedia.org/wiki/Historia_Ziemi

[2] https://www.geografia24.eu/geo_prezentacje_pr_1/301_4_hydrosfera/r1_4_01a.pdf

[3] http://mlodyhydrolog.pl/bazawiedzy/baza/woda-to-zycie/9

[4] https://cordis.europa.eu/article/id/205487new-theory-could-reveal-the-microscopic-nature-of-black-holes/pl

[5] https://mityczne.pl/?s=woda

[6] https://pl.wikipedia.org/wiki/Abisal

[7] http://muzeum.pgi.gov.pl/lekcje_int/morza/srodowisko_abiotyczne.htm

[8] https://www.edukator.pl/resources/page/oceany-i-morza/11084

[9] http://www.astronoo.com/en/articles/life-inthe-abyss.html

[10]https://www.australiangeographic.com.au/blogs/creatura- blog/2014/03/tripod-fish-a-fish-withleg/

[11] https://www.marinebio.org/species/vampiresquid/vampyroteuthis-infernalis/

[12] https://oceana.org/marine-life/cephalopods-crustaceans-other-shellfish/dumbo-octopus

[13] https://singularityhub.com/2021/03/09/thisstingray-like-soft-robot-went-35000feet-below-sea-level-and-thrived-there/

Notka o autorce: Studentka Oceanografii o artystycznej duszy. Kocha fotografować, pisać różne formy literackie, grać w filmach i teatrze oraz reżyserować autorskie filmy. W przysztości chciataby robić to, co jest jej największa pasja. W wolnych chwilach uwielbia przebywać na tonie natury 